\title{
Technique of Tax Rates and Customs Duties Updating as the Tool of Enterprises Innovative Activity Stimulation
}

\author{
Andrey Sergeevich Nechaev ${ }^{1} \&$ Oksana Victorovna Antipina ${ }^{1}$ \\ ${ }^{1}$ Irkutsk State Technical University, Irkutsk, Russia Federation \\ Correspondence: Andrey Sergeevich Nechaev, Irkutsk State Technical University, 664074 Irkutsk, Russia \\ Federation. E-mail: antipina_oksana@mail.ru
}

Received: September 21, 2014

Accepted: September 21, $2014 \quad$ Online Published: December 10, 2014

doi:10.5539/mas.v9n2p87

URL: http://dx.doi.org/10.5539/mas.v9n2p87

\begin{abstract}
Purpose: one of the actual economic science problems is the study of the tax loading influence to the economic activity of the managing subjects which are carrying out an innovative activity. Thus an innovative activity of a business is one of the basic factors capable to provide the innovative development of the country as a whole. The article purpose is the study of the approaches directed to the decrease of the managing subjects' tax loading. Methods: in the course of the research the comparative analysis methods and the statistical methods of research were used. Results: Firstly, on the results of the research conducted the algorithm of the taxes and duties sums calculation was developed on the basis of the tax and customs rates updating taking into account a the admissible limits establishment of their change depending on the activity efficiency of the innovatively active managing subjects promoting their activity activization at the expense of the effective utilization of labor, financial, industrial resources at all stages of the innovations life cycle. Secondly, the universal complex technique of the tax rates and the customs duties updating was offered allowing operating the rates of federal, regional, local taxes and also the export and import customs duties depending on the efficiency activity results of the innovatively active managing subjects at scientific, technical, technological and operational stages of the innovations life cycle.
\end{abstract}

Keywords: innovatively active managing subjects, tax rates, innovative activity

\section{Introduction}

\subsection{Especially Innovative Development}

The National innovative system formation of the Russian Federation is one of the key priority directions in the development of the country. Thus the most number of the enterprises possess a low level of an innovative activity. The principal reasons constraining the innovative development are the disinterest of the state and business structures in the realization of the innovative activity; the lack of the own financial resources; high innovative risks, etc. The important factor is also the level of the tax loading to the innovatively active managing the subjects which makes the essential impact to the efficiency of their activity.

Features of the innovation studied in the works Shumpeter J.A. (Shumpeter, 1961), Kondratyev N.D. (Kondratyev, 1984), Porter M. (Porter, 1985), Kuznets S. (Kuznets, 1955), Drucker P. (Drucker, 1985, 2013), Nechaev A.S., Prokopeva A.V. (Nechaev and Prokopeva, 2013), Yakovets Y. (Yakovets, 1999).

\subsection{Ways of the Tax Stimulation Activity Innovative Enterprises}

Analysis of the impact of the tax burden on businesses represented in the works of Ananiashvili Y. (Ananiashvili, 2010), Laffer A. (Laffer et al., 2008), Canto V. (Canto et al., 1983), Ebrill, L. (Ebrill, 1999).

There are various ways of the enterprises innovative activity tax stimulation used in the domestic and the foreign practice as well. For example, in the foreign countries the tax privileges are more often applied to the research and developmental works (SRECW) in the form of the discounts from the expenses of the company for these purposes (Laffer et al., 2008).

Further it is necessary to note the tax credit as one more of the most widespread forms of the innovative activity stimulation. The given credit is easier and cheaper in a registration and it is widely used in France and the USA (Ananiashvili, 2010). Also the tax deductions which can be based on the sum of the company expenses for the 
research and development and on the gain of expenses for the research and development for the last years (the faster they grow the more the discount) are widespread in many world countries (Ivanova, 2009).

Thus, in our opinion the use of the tax stimulation various methods of the managing subjects should directly depend on the efficiency of their activity.

\section{Methods}

One of the basic problems of the innovative activity realization of the managing subjects is the absence of the sufficient financial resources. Thus the existing system of the taxation does not create the stimulus for the increase of the innovative activity efficiency of the enterprises by means of the money resources economy at the taxes payment in the case of the improvement of the activity indicators in the current period in comparison with the previous one. In turn, the released funds can be invested in the activity of the innovatively active managing subjects and it will promote the annual improvement of the enterprises activity indicators.

\subsection{The Algorithm of the Taxes and Duties Sums Calculation at the Tax and Customs Rates Updating}

For the decision of the described problem we offer the algorithm of the tax rates change taking into account the establishment of the minimum admissible limits of their reduction depending on the efficiency of the innovatively active managing subjects' activity which is presented on Figure 1. 


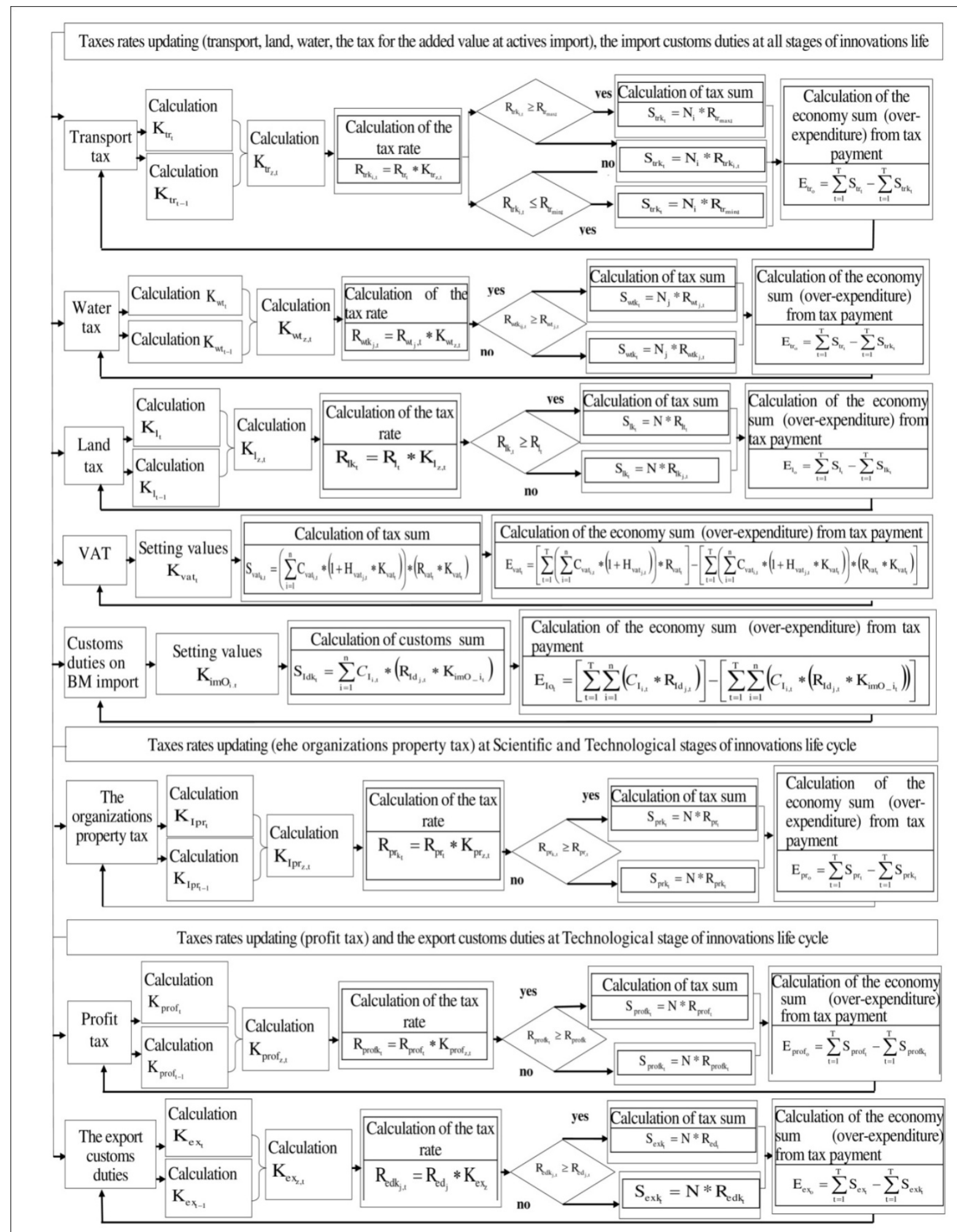

Figure 1. The algorithm of the taxes and duties sums calculation at the tax and customs rates updating taking into account the minimum admissible limits establishment of their reduction depending on the activity efficiency of the innovatively active managing subjects 
Where:

$K_{t r} \quad$ factor of the vehicle replacement

$K_{t r}$

$R_{t r} \quad$ the rate of the tax provided by the legislation of the

$R_{t r} \quad$ Russian Federation, in shares

$S_{r r} S_{v r} \quad$ tax sum

${ }_{N}{ }_{N} \quad$ the taxable base

$E_{v r} E_{r r} \quad$ the economy sum of the transport tax

$K_{w t} \quad$ water consumption factor

$K_{w t}$

$R_{w t} \quad$ the rate of the tax

$R_{w t}$

$S_{w t} S_{w t} \quad$ tax sum

$E_{v t} \quad$ the economy sum of the tax

$E_{\mathrm{w} t}$

$K_{\text {imo }_{i}} \quad$ Adjustment factor of the import duty on BM

$K_{i m O_{i}} \quad$ import

$S_{\text {Idk }} \quad$ sum of the import duty

$S_{\text {Idk }}$

$C_{I} \quad$ value of imports

$C_{I}$

$R_{I d} \quad$ the rate of import duty

$R_{I d}$

$K_{\text {prof }} \quad$ Factor of industrial costs (factor of expenses

$K_{\text {prof }} \quad$ operation )

$R_{\text {prof }} \quad$ the rate of the tax

$R_{\text {prof }}$

$S_{\text {prof }} \quad$ tax sum

$S_{\text {prof }}$

$E_{\text {prof }}$ the economy sum of the tax

$E_{\text {prof }}$

$K_{e x} \quad$ the correction factor of export customs duty

$K_{e x}$

$R_{e d} \quad$ the rate of export duty

$R_{e d}$

$S_{e x} \quad$ the amount of customs duty

$S_{e x}$
$K_{l} \quad$ Factor of effective ground resources

$K_{l} \quad$ utilization

$R_{l} \quad$ the rate of the tax

$R_{l}$

$S_{l} S_{l} \quad$ tax sum

$E_{l} E_{l} \quad$ the economy sum of the tax

$K_{\text {vat }}$ Adjustment factor of import VAT

$K_{\text {vat }}$

$S_{\text {vat }} \quad$ tax sum

$S_{\text {vat }}$

$C_{\text {vat }} \quad$ value

$C_{\text {vat }}$

$H_{v a t} \quad$ the amount of VAT

$H_{\text {vat }}$

$K_{I p r} \quad$ the ratio of fixed assets depreciation

$K_{I p r}$

$R_{p r} \quad$ the rate of the tax

$R_{p r}$

$S_{p r k} \quad$ tax sum

$S_{p r k}$

$E_{p r} \quad$ the economy sum of the tax

$E_{p r}$

$K_{F p r} \quad$ Capital intensity factor

$K_{F p r}$

$R_{p r} \quad$ the rate of the tax

$R_{p r}$

$S_{p r} \quad$ tax sum

$S_{p r}$

$K_{p e r} \quad$ Estimation factor of manpower use efficiency

$K_{p e r}$

$R_{p e r} \quad$ the rate of the tax

$R_{p e r}$

$S_{\text {pr }} \quad$ tax sum

$S_{\text {per }}$

${ }^{t}{ }^{t} \quad$ current period

$t-1$ period previous to the reported one

$t-1$

The developed algorithm of the tax rates change taking into account the minimum admissible limits establishment of their reduction allows at the expense of the lowering tax rate factors application reflecting the dynamics of the managing subjects activity economic indicators to increase their own financial resources needed for the realization of the innovative activity.

\section{Results}

One of the basic ways of the managing subjects' innovative activity energization and the increase of its efficiency is the rates updating of all tax types paid by the legal bodies based on the application of the various 
factors reflecting the efficiency of the enterprises activity. Besides, the possibility of the guaranteeing the import of the essential equipment for activity of the innovatively active managing subjects in the case of the domestic analogues absence and the creation of more favorable economic conditions for the export of the enterprises production is important. The complex technique of the tax rates updating which is developed for the decision of these problems is stated below.

\subsection{Correction Coefficients of Tax Rates}

Correction coefficients of tax rates to be applied for each stage of innovations life cycle separately. The life cycle includes four stages of innovation: Scientific, Technical, Technological, Operational. We analyzed the following types of taxes and customs duties: payments to off-budget means, the organizations property tax, transport tax, land tax, vat, profit tax, customs duties, water tax. For all types of taxes and customs duties are determined correction factors for the respective stages of the life cycle of innovation.

Thus the basic factors used for the tax rates and the customs duties updating are presented in table 1.

Table 1. Factors used for the tax rates and the customs duties updating

\begin{tabular}{|c|c|c|c|}
\hline Taxes (duties) & Employed factors & Factor calculation & $\begin{array}{l}\text { Stages of innovations life } \\
\text { cycle }\end{array}$ \\
\hline $\begin{array}{l}\text { Payments to } \\
\text { off-budget means }\end{array}$ & $\begin{array}{l}\text { Estimation factor of } \\
\text { manpower use efficiency }\end{array}$ & $\begin{array}{l}\mathrm{K}_{\text {per }} \text { volume of manufactured } \\
\text { production / mid-annual number of } \\
\text { employees }\end{array}$ & $\begin{array}{l}\text { Technological } \\
\text { Operational }\end{array}$ \\
\hline $\begin{array}{l}\text { The organizations } \\
\text { property tax }\end{array}$ & $\begin{array}{l}\text { Deterioration factor } \\
\text { of basic means (BM) } \\
\text { Capital intensity factor }\end{array}$ & $\begin{array}{l}\mathrm{K}_{\mathrm{r}} \text { deterioration of } \mathrm{BM} / \text { initial cost of } \\
\mathrm{BM} \\
\mathrm{K}_{\mathrm{f}=\text { mid-annual cost of the basic means }} \\
\text { /a gain }\end{array}$ & $\begin{array}{l}\text { Scientific } \\
\text { Technical } \\
\text { Technological } \\
\text { Operational }\end{array}$ \\
\hline Transport tax & $\begin{array}{l}\text { Factor of vehicles } \\
\text { replacement }(\mathrm{V})\end{array}$ & $\begin{array}{l}\mathrm{K}_{\mathrm{tr}}=\text { cost of the } \mathrm{V} \text { with drawn as a } \\
\text { result of deterioration / cost of } \mathrm{V} \\
\text { obtained again }\end{array}$ & $\begin{array}{l}\text { Scientific } \\
\text { Technical } \\
\text { Technological } \\
\text { Operational }\end{array}$ \\
\hline Land tax & $\begin{array}{l}\text { Factor of effective } \\
\text { ground resources } \\
\text { utilization }\end{array}$ & $\begin{array}{l}\mathrm{K}_{l}=\text { not used ground area / the general } \\
\text { ground area. }\end{array}$ & $\begin{array}{l}\text { Scientific } \\
\text { Technical } \\
\text { Technological } \\
\text { Operational }\end{array}$ \\
\hline VAT & $\begin{array}{l}\text { Adjustment factor of } \\
\text { import VAT }\end{array}$ & $\mathrm{K}_{\mathrm{VATO}=\text { legislatively established }}$ & $\begin{array}{l}\text { Scientific } \\
\text { Technical } \\
\text { Technological } \\
\text { Operational }\end{array}$ \\
\hline Profit tax & $\begin{array}{l}\text { Factor of industrial } \\
\text { costs (factor of } \\
\text { expenses operation ) }\end{array}$ & $\begin{array}{l}\mathrm{K}_{\text {prof }}=(\text { prime cost }+ \text { operational } \\
\text { expenses) } / \text { gain }\end{array}$ & Technological - consumption \\
\hline \multirow[t]{4}{*}{ Customs duties } & $\begin{array}{l}\text { Adjustment factor of the } \\
\text { import duty on BM } \\
\text { import }\end{array}$ & $\begin{array}{l}1-\mathrm{K}_{\mathrm{imO} \_1} \\
2-\mathrm{K}_{\mathrm{imO} \_2}\end{array}$ & $\begin{array}{l}\text { Scientific - import - } \\
\text { unturnable } \\
\text { Technical - }\end{array}$ \\
\hline & & $3-\mathrm{K}_{\mathrm{imO} \_}$ & $\begin{array}{l}\text { import-unturnable } \\
\text { Technological - import - } \\
\text { unturnable }\end{array}$ \\
\hline & & $4-\mathrm{K}_{\mathrm{imO} \_4}$ & $\begin{array}{l}\text { Operational - import - } \\
\text { unturnable }\end{array}$ \\
\hline & $\begin{array}{l}\text { The correcting factor } \\
\text { on finished goods } \\
\text { export }\end{array}$ & $\begin{array}{l}К_{\text {ренИзд - factor of industrial costs }} \\
\text { (factor of operation of expenses) }= \\
\text { prime cost }+ \text { operational expenses / a } \\
\text { gain }\end{array}$ & Technological \\
\hline Water tax & $\begin{array}{l}\text { Water consumption } \\
\text { factor }\end{array}$ & $\begin{array}{l}\mathrm{K}_{\mathrm{wt}} \text { factual expense of water by water } \\
\text { consumed unit / norm of water } \\
\text { consumption }\end{array}$ & $\begin{array}{l}\text { Scientific } \\
\text { Technical } \\
\text { Technological } \\
\text { Operational }\end{array}$ \\
\hline
\end{tabular}


Let's examine the abovementioned technique on the example of the transport tax and the customs duties at the finished goods export.

\subsection{The Rate of the Transport Tax Updating at All Stages of the Innovations Life Cycle}

Let's calculate under the formulas the factor of the vehicles replacement in the current (reported) period $t(1)$ and the period previous to the reported one $\mathrm{t}-1$ (2):

$$
\begin{array}{rlrl}
K_{t r_{t}} & =\frac{\sum_{i=1}^{n} P_{i, t}\left(1-\frac{j}{L_{i}}\right)}{\sum_{i=1}^{n} C P_{i, t}} \\
K_{t r_{t}} & =\frac{\sum_{i=1}^{n} P_{i, t}\left(1-\frac{j}{L_{i}}\right)}{\sum_{i=1}^{n} C P_{i, t}} & K_{t r_{t-1}} & =\frac{\sum_{i=1}^{n} P_{i, t-1}\left(1-\frac{j-1}{L_{i}}\right)}{\sum_{i=1}^{n} C P_{i, t-1}} \\
K_{t r_{t-1}} & =\frac{\sum_{i=1}^{n} P_{i, t-1}\left(1-\frac{j-1}{L_{i}}\right)}{\sum_{i=1}^{n} C P_{i, t-1}}
\end{array}
$$

Where: $K_{t r_{t}}$ factor of the vehicle replacement (V) in the current period; $K_{t t_{t-1}}$ factor of replacement of $\mathrm{V}$ in the period previous to the current period; ${ }^{P_{i}}$ - initial cost of V; $C P_{i, t}$ - cost of the obtained vehicles in the current period; ${ }^{L_{i}}$ term of useful use of $\mathrm{V}^{j}{ }^{j}$ - year of $\mathrm{V}$ use $;{ }^{n}$ - quantity of the $\mathrm{V} ;{ }^{T}$ - the considered period, in years.

Calculation of the transport tax rate taking into account the correcting factor (CF) is made under the formula (3). $\mathrm{CF}$ rates of the transport tax are calculated under the formula (4):

$$
\begin{aligned}
& R_{t r k_{i, t}}=R_{t r_{t}} * K_{t r_{z, t}} \\
& R_{t r k_{i, t}}=R_{t r_{t}} * K_{t r_{z, t}}
\end{aligned}
$$

$$
K_{t r_{z, t}}=\frac{K_{t r_{t}}}{K_{t r_{t-1}}} K_{t r_{z, t}}=\frac{K_{t r_{t}}}{K_{t r_{t-1}}}
$$

Where: $R_{t t_{i, t}}$ - the rate of the tax provided by the legislation of the Russian Federation, in shares; $R_{t r k_{i, t}}$ - the rate of the transport tax taking into account the correcting factor; ${ }^{t r_{z, t}}$-CF rates of the transport tax of the current (reported) period.

If $K_{t r_{z, t}} \succ k$, then $K_{t r_{z, t}}=k$; if $K_{t r_{z, t}} \prec \frac{1}{k}$, then $K_{t r_{z, t}}=\frac{1}{k}$, where $k$ - increase / reduction degree of the admissible rate of the transport tax (according to p. 1 of item $361 \mathrm{TC}$ the Russian Federation the rates of the transport tax can be increased / reduced but no more than in 10 times. In this connection $k=10$ ).

Thus the total sum of economy (over-expenditure) of the transport tax for all period of CF application will be defined under the formula:

$$
E_{t r_{o}}=\sum_{t=1}^{T} \sum_{i=1}^{n}\left(N_{i_{t}} * R_{t r_{i, t}}\right)-\left(\sum_{i=1}^{n}\left(N_{i_{1}} * R_{t r_{i, 1}} * K_{t r_{z, 1}}\right)+\sum_{t=2}^{T} \sum_{i=1}^{n}\left(N_{i_{t}} * R_{t r_{i, t-1}} * K_{t r_{z, t}}\right)\right)
$$




$$
E_{t r_{o}}=\sum_{t=1}^{T} \sum_{i=1}^{n}\left(N_{i_{t}} * R_{t r_{i, t}}\right)-\left(\sum_{i=1}^{n}\left(N_{i_{1}} * R_{t r_{i, 1}} * K_{t r_{z, 1}}\right)+\sum_{t=2}^{T} \sum_{i=1}^{n}\left(N_{i_{t}} * R_{t r_{i, t-1}} * K_{t r_{z, t}}\right)\right)
$$

Where: $E_{t r}$ - the economy sum of the transport tax $N_{i}$-the taxable base of the transport tax (the tax base is defined whether as the capacity of the engine of a vehicle in horsepower's or as the gross tonnage in register tons; or as vehicle unit).

The given mathematical model allows calculating the total sum of economy (over-expenditure) on the transport tax payment for all period of CF application.

\subsection{Customs Duties updating at the Finished Goods Export}

Let's calculate under CF formulas the rates of the customs duties at the finished goods export to the current (reported) period $t(6)$ and the period previous to the reported onet-1 (6):

$$
\begin{aligned}
& K_{e x_{t-1}}=\sum_{i=1}^{n} \frac{\left(Q_{i_{t}}+V_{i_{t}}\right)}{G_{i_{t}}} \\
& K_{e x_{t-1}}=\sum_{i=1}^{n} \frac{\left(Q_{i_{t}}+V_{i_{t}}\right)}{G_{i_{t}}}
\end{aligned}
$$

$$
\begin{aligned}
& K_{e x_{t-1}}=\sum_{i=1}^{n} \frac{\left(Q_{i_{t-1}}+V_{i_{t-1}}\right)}{G_{i_{t-1}}} \\
& K_{e x_{t-1}}=\sum_{i=1}^{n} \frac{\left(Q_{i_{t-1}}+V_{i_{t-1}}\right)}{G_{i_{t-1}}}
\end{aligned}
$$

Where: ${ }^{K_{x_{t}}}$ the factor of the industrial costs in the current period; ${ }^{K_{x_{t-1}}}$ the factor of the industrial costs in the period previous to the current period; ${ }^{Q_{i}}$ - the cost price of the exported production; $V_{i}$ - the operational expenses; ${ }^{G_{i}}$ - a gain; $n$ - the quantity of the exported production types.

The calculation of the export customs duties rate taking into account $\mathrm{CF}$ is made under the formula (7). CF rates of insurance payments are calculated under the formula (8):

$$
\begin{aligned}
& R_{e d k_{j, t}}=R_{e d_{j}} * K_{e x_{z}} \\
& R_{e d k_{j, t}}=R_{e d_{j}} * K_{e x_{z}}
\end{aligned}
$$

$$
K_{e x_{z}}=\frac{K_{e x_{t}}}{K_{e x_{t-1}}} K_{e x_{z}}=\frac{K_{e x_{t}}}{K_{e x_{t-1}}}
$$

Where: $-R_{e d_{j}}$ the rate of the export customs duties applied to corresponding type of the exported production; ${ }^{R_{\text {ext }}}$ the rate of the export customs duties taking into account the correcting factor applied to the corresponding type of the exported production; - $K_{e_{2}} \mathrm{CF}$ of the export customs duties on the finished goods export.

Thus the total sum of the economy (over-expenditure) from payment of the export customs duties for all period of $\mathrm{CF}$ application will be defined under the formula:

$$
\begin{aligned}
& E_{e x_{o}}=\left[\sum_{t=1}^{T} \sum_{i=1}^{n}\left(C_{e x_{i, t}} * R_{e d_{j, t}}\right)\right]-\left[\left(\sum_{i=1}^{n} C_{e x_{i, 1}} *\left(R_{e d_{i, 1}} * K_{e x_{z, t}}\right)\right)+\left(\sum_{t=2}^{T} \sum_{i=1}^{n} C_{e x_{i, t}} *\left(R_{e d_{i, t-1}} * K_{e x_{z, t}}\right)\right)\right] \\
& E_{e x_{o}}=\left[\sum_{t=1}^{T} \sum_{i=1}^{n}\left(C_{e x_{i, t}} * R_{e d_{j, t}}\right)\right]-\left[\left(\sum_{i=1}^{n} C_{e x_{i, 1}} *\left(R_{e d_{i, 1}} * K_{e x_{z, t}}\right)\right)+\left(\sum_{t=2}^{T} \sum_{i=1}^{n} C_{e x_{i, t}} *\left(R_{e d_{i, t-1}} * K_{e x_{z, t}}\right)\right)\right]
\end{aligned}
$$

Where: $-E_{e x}$ the sum of the economy (over-expenditure) on payment of the export customs duties; ${ }^{-{ }^{e x}}{ }_{i}-$ the cost of the exported finished goods.

The given mathematical model allows calculating the total sum of the economy (over-expenditure) on payment of the export customs duties for all period of CF application. 


\section{Discussion}

One of the most important long-term challenges Russia is strengthening the innovation component of their economic development. Transition to the innovative economy - the only way to recovery and development of the economic potential of Russia. However, the implementation of innovative development in practice, essentially blocked the same branches as a result of failure to take necessary decisions to stimulate innovative activity.

In all countries where there are processes of transition to a post-industrial information society, the structural changes were not immediately and not for the entire territory, and the first - in the regions, the most prepared for the restructuring. In the United States such areas were primarily Silicon Valley (near San Francisco) and District Highway 128 (Boston and area adjacent to the north-east). In Japan, similar changes occurred in the industrial belt of Tokyo - Osaka in France - in the department of Hilda-France, the bulk of which is Grand Paris; in the UK - in the "corridors" London, Liverpool, Edinburgh and Glasgow; in China - in the coastal free economic zones, etc. Such a focus of high-tech exhibited rapid growth of industrial production, employment, standard of living, in stark contrast with the regions is in decline of traditional industries, where there were mass unemployment and other crises.

From a wide arsenal of measures developed in this area of the world practice, it is necessary to select the appropriate current situation and Russian specifics. The selection coefficients for adjustment of tax rates we analyzed in the works Atkinson R., Ezell S. (Atkinson and Ezell 2012), Folomev A., Revazov V. (Folomev and Revazov 2001), Gadzhiev U., Akopov V., Styrov M. (Gadzhiev et al., 2009), Gluschenko I. (Gluschenko, 2009), Kamenskaja O. (Kamenskaja, 2011)., Lenchuk E. (Lenchuk and Vlaskin, 2005), Zaikina N. (Zaikina, 2010).

The most important are the three main methods: tax incentives, incentives through depreciation policy (not as part of the fiscal policy, but as an independent mechanism), direct budget subsidies to companies developing new products.

\section{Conclusion}

Thus, the offered algorithm and the technique of the tax rates are one of the basic ways of the enterprises activity.

The developed algorithm of the tax rates change determines the minimum admissible limits establishment of their reduction. Moreover our algorithm allows to increase financial resources for the innovative activity enterprises at the expense of the application of the lowering tax rate factors. The change in tax rates should depends on the dynamics of the economic indicators of the managing subjects activity.

The universal complex technique of the tax rates updating allows stirring up the innovatively active managing subjects activity. This is possible due to the annual to changes in the sum of payment on all types of tax depending on the results of activity enterprises.

Besides, the given technique creates more favorable economic conditions for the import of the necessary equipment for the enterprises innovative activity (in the case of the domestic analogues absence). This is possible due to changes in the rate of customs duty at the import of BM and VAT at the actives import.

Also the given technique creates more favorable economic conditions for the finished goods export of the innovatively active managing subjects at the expense of the modified export customs duties application.

It is necessary to specify the number of the given work restrictions. Firstly, nowadays there is no common opinion concerning the efficiency of those or other tools application for the tax stimulation. Secondly, we use only one updating factor in the offered algorithm and the developed technique for each type of tax.

In connection with the above-stated the possible prospects of the further researches can be connected with the system of the interconnected correcting factors taking into account the branch specificity of the enterprises.

\section{References}

Ananiashvili, Y. (2010). Taxes and macroeconomic equilibrium: the Laffer-Keinsian synthesis. Stockholm: SF \& CC Press.

Atkinson, R. D., \& Ezell, S. J. (2012). Innovation Economics: The Race for Global Advantage. Yale University Press, pp: 440.

Canto, V., Joiness, D., \& Laffer, A. (1983). Foundations of Supply-Side Economics: Theory and Evidence. New York: Academic Press.

Drucker, P. F. (1985). Innovation and Entrepreneurship. New York: Harper \& Row.

Drucker, P. F. (2013). On Innovation. Boston: Harvard Business School Publishing Corporation, pp: 176. 
Ebrill, L. (1999). Tax Reform in the Baltics, Russia and Other Countries of the Former Soviet Union. Occasional Paper, 182.

Folomev, A., \& Revazov, V. (2001). Innovative investment. St. Petersburg: Science, pp: 184.

Gadzhiev, U., Akopov, V., \& Styrov, M. (2009). Interregional distinctions in scientifically-innovative potential of the Russian Federation. Society and economy, 2, 156-179.

Gluschenko, I. (2009). Policy innovation financing enterprise. Finance and credit, 18, 35-45.

Ivanova, N. (2009). Tax stimulation of innovative processes. Moscow: Russian Academy of Sciences.

Kamenskaja, O. V. (2011). Complex quality standard of innovative activity. Russian business, 4, 43-48.

Kondratiev, N. D. (1984). The Long Wave Cycle. New York: Richardson \& Snyder.

Kuznets, S. (1955). Economic Growth and Income Inequality. American Economic Review, 45, 1-28.

Laffer, A., Moore, S., \& Tanous, P. (2008). The End of Prosperity: How Higher Taxes will Doom the Economy if We Let it Happen. New York: Threshold Editions.

Lenchuk, E. B., \& Vlaskin, G. A. (2005). Financing of innovative activity in Russia. EKO, 12(9-26).

Nechaev, A. S, \& Prokopeva, A. V. (2013). Key features of risks of company innovative activities. Middle East Journal of Scientific Research, 17(2). http://dx.doi.org/10.5829/idosi.mejsr.2013.17.02.12187

Porter, M. E. (1985). Competitive Advantage. New York: Free Press.

Shumpeter, J. (1961). The Theory of Economic Development. New York: Oxford University Press.

Yakovets, Y. (1999). Cycles. Crises. Forecasts. Moscow: Nauka, pp: 448.

Zaikina, N. A. (2010). Method of assessing the effectiveness of innovation departments of industrial enterprises. Journal of Economics, 6, 63-67.

\section{Copyrights}

Copyright for this article is retained by the author(s), with first publication rights granted to the journal.

This is an open-access article distributed under the terms and conditions of the Creative Commons Attribution license (http://creativecommons.org/licenses/by/3.0/). 